\title{
Successful Treatment of Unilateral Cryptorchid Boys Risking Infertility with LH-RH Analogue
}

\author{
Faruk Hadziselimovic
}

Kindertagesklinik, Liestal, Switzerland

\begin{abstract}
Introduction: Infertility is the primary concern for boys with uni- or bilateral undescended testes. An early and seemingly successful orchiopexy does not improve fertility in a substantial number of cryptorchid males. We confirmed that LH-RH analogue (LH-RHa) treatment induces an increase in and maturation of the germ cells; however, it was uncertain if treatment would improve the chance of fertility later in life.

Materials and Methods: Thirty unilateral cryptorchid boys, with an average age of 3 years at the time of surgery, were included in the study. Testicular biopsy showed that they had impaired testicular maturation and were therefore at high risk for infertility. Fifteen of the 30 unilateral cryptorchid boys were treated with $10 \mu \mathrm{g}$ LH-RHa (Buserelin) nasal spray, administered on alternate days for a period of 6 months, following orchiopexy. The control group consisted of 15 cryptorchid boys who had been treated by Schoemakers type of orchiopexy, alone. After puberty, the ejaculates of both groups were analyzed.

Results: All males in the untreated group were severely oligospermic, with $20 \%$ being azoospermic. In contrast, $86 \%$ of the treated ex-cryptorchid males had a sperm concentration within the normal range; this was significantly different from the sperm concentration found in the untreated group $(\mathrm{p}=0.000008)$.

Conclusion: For the first time, we demonstrate that infertility in cryptorchidism can be successfully corrected when suitably treated with a LH-RHa. Sperm parameters normalized following therapy in the majority of cryptorchid males who, untreated, would have remained infertile. This innovative hormonal treatment will have a profound effect on the current recommended surgical treatment of boys with undescended testes.
\end{abstract}

Key words: cryptorchidism; sperm; Ad spermatogonia; fertility; LH-RH analogue; treatment

Int Braz J Urol. 2008; 34: 319-28

\section{INTRODUCTION}

Cryptorchidism is the most common urogenital birth-defect in males, necessitating surgery in about 27,000 boys each year in the United States (1). Since 1960, when Charny stated that "the surgical techniques currently practiced by most surgeons must improve significantly, albeit the cosmetic results are arguably better but the functional results fall far short of the intent" very little has changed (2). Although the effect on testicular development and fertility has been studied extensively since that time, there is only one general consensus: untreated boys with bilateral undescended testes will be infertile.

In 1975, Ludwig and Potempa found that the fertility rate is inversely proportional to the age of the patient at the time of surgery. Consequently, it was expected that infertility resulting from cryptorchidism 
could be cured if orchiopexy was performed before the second year of life (3). Thirty years later, when the fertility results of early surgery were obtainable, we realized that the therapeutic strategy to operate before the age of 2 years had not improved fertility hopes in a substantial number of cryptorchid patients (4). Cryptorchid boys lacking Ad spermatogonia will be infertile despite a seemingly successful orchiopexy at an early age (4). The main cause is impaired mini-puberty, the surge of gonadotropins and testosterone that occurs in early infancy (5). In an attempt to correct impaired mini-puberty, we administered a LH-RH analogue to cryptorchid boys following successful surgery and achieved an increase in the number of germ cells (6). We report the results of the first 15 patients treated with LH-RHa after successful surgery, who are now young adults, and compare the outcomes with patients who were treated with surgery only. The amelioration of testicular maturation appears to result in the normalization of excretory testicular function.

\section{MATERIALS AND METHODS}

Fifteen unilateral cryptorchid boys who had a Schoemakers type of orchiopexy between the ages of 1-6 years were subsequently treated with LH-RH. Their cryptorchid testes were located outside of the scrotum since birth. A vast majority had testes located inguinal or at external inguinal ring. Two patients, one of each in treated and untreated group had testes located in abdomen. Twelve out of 15 patients had an unsuccessful HCG treatment before surgery. Testicular biopsies were obtained during orchiopexy, fixed in 3\% glutaraldehyde, and embedded in Epon. Semi-thin sections, $1 \mu$ thick, were examined with light microscopy. At least 100 tubular cross sections were counted to estimate the total number of germ cells per testis. The entire biopsy was analyzed for the occurrence of Ad spermatogonia. All patients had $<0.2$ germ cells per tubular cross section (normal $>$ 2 per tubular cross section) and none had Ad (dark) spermatogonia. Therefore, these patients were at high risk of being infertile $(7,8)$. Within 3 months following surgery, treatment with the LH-RH analogue Buserelin, a nonapeptide ethilamide of D-Ser $\left(\mathrm{Bu}^{\mathrm{t}}\right)^{6} \mathrm{LH}-\mathrm{RH}$, was initiated, with $10 \mu \mathrm{g}$ applied as an intranasal spray in the evening on alternate days for a period of 6 months. All patients had regular monthly check-ups during the course of treatment. The boys' mothers were questioned about compliance to the nasal spray treatment as well as possible adverse side effects of the medication. Furthermore, their general well being and genital status were estimated, including determining testicular volume, penile length with a ruler, and Tanner stage of sexual development.

These 15 patients, who are now young adults, were among the first to receive LH-RH analogue treatment at the ages of 1-6 years (average age, 3 years; 95\% CI 2 - 4 years). They were recruited from a group of 19 who were invited to participate in the study, and were older than 18 years of age. None of the patients had additional surgeries or severe illness requiring hospitalization during the 15-19 years following treatment. Twelve of 15 were non-smokers and none was on chronic medication or was drug abusers. During a very recent medical check-up, their general status and Tanner stage of pubertal development was appraised. Testicular volume and the length of stretched penis were measured. Testicular volume was determined according to the formula; $V=4 / 3 \times \pi$ $\mathrm{x} \mathrm{D} / 2 \mathrm{x} \mathrm{d}^{2} ;\left(0.71 \mathrm{x} \mathrm{D} \mathrm{x} \mathrm{d}^{2}\right)$. An ejaculate was collected following sexual abstinence for at least 5 days. Semen analysis was performed by computer-assistance and additionally confirmed with repeated microscopic examinations. In accordance with WHO standards, infertility was assumed if the sperm concentration was $<40 \times 10^{6}$ per ejaculate (9). All patients with a sperm concentration within the infertile range had at least a second ejaculate analyzed within 2-4 weeks. The better sperm concentration of the 2 evaluations was included in the study. The majority $(8 / 15)$ of patients had to deliver their sperm specimens by mail; therefore, sperm motility could not be evaluated. Nevertheless, sperm concentration, ejaculate volumes, and sperm morphology with teratozoospermic index were evaluated.

The age-matched control group was selected from 181 unilateral cryptorchid patients who had had their sperm ejaculates analyzed. Patients in the control group had all undergone a successful Schoemaker type orchiopexy and a testicular biopsy was obtained during the surgery; however, they did not 
undergo additional LH-RH treatment. Fifteen of the 181 fulfilled the same criteria as the treated group and were included in the control group. They all had unilateral cryptorchidism, were the same age at treatment (average age, 4 years; 95\% CI 2-6; $\mathrm{p}=0.35$ ), had no Ad spermatogonia, and had a total number of germ cells $<0.2$ per tubule. 13 out of 15 patients had an unsuccessful HCG treatment prior to surgery.

\section{Statistical Analysis}

The recruitment of patients for this, non randomized, study was designed to be balanced. Given the customary values for the significance level $\alpha=$ 0.05 and the power $\beta=90 \%$ and using the module "MTT1-1" in the software "nQuery Advisor" The sample sizes are determined to $\mathrm{N}=12$ for a one-sided and to $\mathrm{N}=14$ for the two-sided Wilcoxon/MannWhitney U-test.

Following assumptions were entered into the module "MTT1-1" of nQuery Advisor: That the mean sperm count in the treated group was larger than 40 millions whereas in the untreated group it was smaller than 10 millions where standard deviation was estimated to be smaller than 20 millions.

We therefore first analyzed the group of 181 ex-unilateral cryptorchid males who were only surgically treated and identified 15 who fulfilled the entry requirements for the study. Consequently, we invited our first 19 ex-unilateral cryptorchid males, who had LH-RHa treatment and were older than 18 years, to participate in the study. Fifteen of the first consecutive responders entered the study. The Mann-Whitney $U$ test for unpaired data was used in the software package StatXact 6.30 (2004) from CYTEL Corporation. Nonparametric 95\% confidence intervals for the medians were computed by bootstrapping.

\section{Ethical Considerations}

In accordance with the Helsinki declaration, the Institutional Review Board (IRB), and the Independent Ethics Committee of University Children's Hospital Basel approved all aspects of this study. In particular, approval was given for research involving the use of material (data, documents, records or specimens) that had been collected for non-research purposes.

\section{RESULTS}

The total number of germ cells in the surgery "only" group was an average of 0.02 germ cells per tubular cross section ( $95 \%$ CI: 0 - 0.2). This was the same as the number observed in the treated group, who had an average of 0 germ cells per tubular cross section (95\% CI: 0.- 0.05; $\mathrm{p}=0.22$ ). Both groups had no Ad (dark) spermatogonia present in their entire testicular biopsies. Indicating defective germ cell transformation due to an impaired mini puberty.

There were no adverse side effects and no changes in the Tanner stage of pubertal development during the hormonal treatment.

Most often, mothers reported that their boys were more active than usual during treatment. Testicular volume remained unchanged compared with that before the treatment, while there was a significant increase in penile length from an average of $4.5 \mathrm{~cm}$ (95\% CI 4-5) before treatment to an average of 5.0 $\mathrm{cm}(95 \%$ CI $4.5-6)$ after treatment $(\mathrm{p}<0.001)$ (Table$1)$.

At a recent examination at an average age of 19 years (95\% CI 18-22), all males were in a healthy condition. They all had Tanner V stage of sexual development and normal erectile function. The length of the stretched penis was in the lower normal limit with average length of $12 \mathrm{~cm}(95 \%$ CI 10-13 cm) (Table-2). Testicular volume of orchiopexy testes was less when compared with the contralateral descended partner; ex-undescended testicle $29 \mathrm{~mL}$ ( $95 \%$ CI 22.- $36 \mathrm{~mL}$ ) vs. contralateral descended testicle $38 \mathrm{~mL}(95 \% \mathrm{CI}$ 30-46 mL; p < 0.0026) (Table-2).

\section{Spermiogram}

In the surgery "only" group, all ex-cryptorchid males suffered severe oligospermia, and 20\% $(3 / 15)$ of the group had azoospermia. The average sperm concentration was $1 \times 10^{6}(95 \%$ CI: $0-13)$ per ejaculate (Figure-1), Table-3.

In the LH-RH treated group, one male had oligospermia and one had a diminished sperm concentration while in the remaining 13 males had a normal sperm concentration, (Table-2). Average total sperm concentration in the treated group was of $90 \times 10^{6}$ (95\% CI: 53-164) per ejaculate (Figure-1). This was significantly different from the sperm concentrations 


\section{Treatment of Cryptorchid Boys with LH-RH Analogue}

Table 1 - Characteristics of the 15 patients with cryptorchidism immediately before and after treatment with luteinizing hormone releasing hormone.

\begin{tabular}{lccccccccccccccc}
\hline Patient & $\mathbf{1}$ & $\mathbf{2}$ & $\mathbf{3}$ & $\mathbf{4}$ & $\mathbf{5}$ & $\mathbf{6}$ & $\mathbf{7}$ & $\mathbf{8}$ & $\mathbf{9}$ & $\mathbf{1 0}$ & $\mathbf{1 1}$ & $\mathbf{1 2}$ & $\mathbf{1 3}$ & $\mathbf{1 4}$ & $\mathbf{1 5}$ \\
\hline $\begin{array}{l}\text { Age at } \\
\text { surgery/ }\end{array}$ & 3 & 4 & 3 & 4 & 2 & 6 & 2 & 6 & 2 & 3 & 3 & 3 & 1 & 3 & 4 \\
$\begin{array}{l}\text { years } \\
\text { Cryptorchid }\end{array}$ & $\mathrm{L}$ & $\mathrm{L}$ & $\mathrm{R}$ & $\mathrm{R}$ & $\mathrm{R}$ & $\mathrm{L}$ & $\mathrm{R}$ & $\mathrm{R}$ & $\mathrm{L}$ & $\mathrm{L}$ & $\mathrm{L}$ & $\mathrm{L}$ & $\mathrm{L}$ & $\mathrm{L}$ & $\mathrm{L}$ \\
$\begin{array}{l}\text { testis } \\
\text { S/T (germ }\end{array}$ & & & & & & & & & & & & & & & \\
$\begin{array}{l}\text { cells/ } \\
\text { tubules) }\end{array}$ & 0.04 & 0 & 0.02 & 0 & 0.1 & 0 & 0 & 0 & 0 & 0.02 & 0 & 0.03 & 0.05 & 0.06 & 0 \\
& & & & & & & & & & & & & & & \\
Ad/tubule & 0 & 0 & 0 & 0 & 0 & 0 & 0 & 0 & 0 & 0 & 0 & 0 & 0 & 0 & 0 \\
& & & & & & & & & & & & & & & \\
Testis & 1.8 & 1.7 & 1.2 & 1.9 & 1.1 & 2.1 & 1.0 & 2.0 & 1.8 & 1.5 & 1.0 & 1.0 & 1.3 & 1.4 & 1.2 \\
volume & $\mathrm{L}$ & $\mathrm{L}$ & $\mathrm{L}$ & $\mathrm{L}$ & $\mathrm{L}$ & $\mathrm{L}$ & $\mathrm{L}$ & $\mathrm{L}$ & $\mathrm{L}$ & $\mathrm{L}$ & $\mathrm{L}$ & $\mathrm{L}$ & $\mathrm{L}$ & $\mathrm{L}$ & $\mathrm{L}$ \\
before & 1.8 & 1.8 & 0.8 & 2.1 & 1.1 & 1.0 & 1.0 & 2.0 & 1.8 & 1.5 & 1.0 & 1.2 & 1.2 & 1.2 & 2.0 \\
(mL) & $\mathrm{R}$ & $\mathrm{R}$ & $\mathrm{R}$ & $\mathrm{R}$ & $\mathrm{R}$ & $\mathrm{R}$ & $\mathrm{R}$ & $\mathrm{R}$ & $\mathrm{R}$ & $\mathrm{R}$ & $\mathrm{R}$ & $\mathrm{R}$ & $\mathrm{R}$ & $\mathrm{R}$ & $\mathrm{R}$ \\
\hline
\end{tabular}

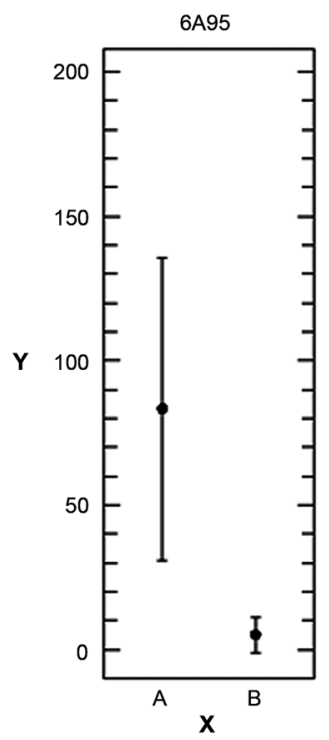

Figure 1 - Sperm concentration/ejaculate in Buserelin treated group (A) and untreated group (B) Mean and SD are demonstrated. $Y=$ number of sperm in million per ejaculate. in the surgery "only" group $(\mathrm{p}=0.000008)$ (Figure-1). Furthermore, in the LH-RHa treated group, the teratozoospermic index and volume of ejaculates were in the normal range (Table-2). If fertility capacity were defined according to the Tygerberg strict criteria, then sperm morphologic pattern was distributed similar to the distribution found in the normal fertile population (10). Two males had P-pattern (poor-prognosis), 8 were in the G-pattern (good prognosis) group, and 5 were in the N-pattern (normal forms $>14 \%$ ) group (Table-2).

\section{COMMENTS}

Attempting to improve the unfavorable fertility results through early treatment of cryptorchidism is generally recommended and accepted today. According to current thinking, hormonal, hormonal/surgical, or only surgical treatment should be completed before the patient's second birthday. However, boys with a severe reduction and im- 
Table 2 - Characteristics of the 15 patients with cryptorchidism initially treated with surgery and luteinizing hormone releasing hormone, at follow-up after puberty.

\begin{tabular}{|c|c|c|c|c|c|c|c|c|c|c|c|c|c|c|c|}
\hline Patient & 1 & 2 & 3 & 4 & 5 & 6 & 7 & 8 & 9 & 10 & 11 & 12 & 13 & 14 & 15 \\
\hline $\begin{array}{l}\text { Age at } \\
\text { spermiogram }\end{array}$ & 21 & 20 & 18 & 19 & 19 & 23 & 18 & 25 & 18 & 19 & 18 & 20 & 20 & 18 & 22 \\
\hline $\begin{array}{l}\text { Testis } \\
\text { volume (mL) }\end{array}$ & $\begin{array}{c}42 \\
\mathrm{~L} \\
52 \\
\mathrm{R}\end{array}$ & $\begin{array}{c}37 \\
\mathrm{~L} \\
52 \\
\mathrm{R}\end{array}$ & $\begin{array}{c}32 \\
\mathrm{~L} \\
11 \\
\mathrm{R}\end{array}$ & $\begin{array}{c}32 \\
\mathrm{~L} \\
35 \\
\mathrm{R}\end{array}$ & $\begin{array}{c}68 \\
\mathrm{~L} \\
57 \\
\mathrm{R}\end{array}$ & $\begin{array}{c}9 \\
\mathrm{~L} \\
13 \\
\mathrm{R}\end{array}$ & $\begin{array}{c}26 \\
\mathrm{~L} \\
32 \\
\mathrm{R}\end{array}$ & $\begin{array}{c}68 \\
\mathrm{~L} \\
43 \\
\mathrm{R}\end{array}$ & $\begin{array}{c}18 \\
\mathrm{~L} \\
32 \\
\mathrm{R}\end{array}$ & $\begin{array}{l}26 \\
\mathrm{~L} \\
42 \\
\mathrm{R}\end{array}$ & $\begin{array}{l}36 \\
\mathrm{~L} \\
34 \\
\mathrm{R}\end{array}$ & $\begin{array}{c}29 \\
\mathrm{~L} \\
48 \\
\mathrm{R}\end{array}$ & $\begin{array}{c}21 \\
\mathrm{~L} \\
22 \\
\mathrm{R}\end{array}$ & $\begin{array}{c}36 \\
\mathrm{~L} \\
45 \\
\mathrm{R}\end{array}$ & $\begin{array}{c}13 \\
\mathrm{~L} \\
29 \\
\mathrm{R}\end{array}$ \\
\hline $\begin{array}{l}\text { Penis } \\
\text { length }(\mathrm{cm})\end{array}$ & 12 & 12 & 12 & 13 & 13 & 10 & 11 & 14 & 9 & 14 & 12 & 10 & 13 & 12 & 12.5 \\
\hline $\begin{array}{l}\text { Tanner stage } \\
\text { genital } \\
\text { development }\end{array}$ & $\mathrm{V}$ & $\mathrm{V}$ & $\mathrm{V}$ & $\mathrm{V}$ & $\mathrm{V}$ & $\mathrm{V}$ & V & $\mathrm{V}$ & $\mathrm{V}$ & $\mathrm{V}$ & $\mathrm{V}$ & $\mathrm{V}$ & $\mathrm{V}$ & $\mathrm{V}$ & V \\
\hline $\begin{array}{l}\text { Sperm } \\
\text { concentration }\end{array}$ & 57 & 53 & 19 & 58 & 198 & 115 & 1 & 94 & 60 & 107 & 164 & 97 & 63 & 180 & 81 \\
\hline $\begin{array}{l}\text { Normal } \\
\text { morphology \% } \\
(\geq 14 \%)\end{array}$ & 7 & 8 & 11 & 11 & 18 & 21 & 0 & 12 & 4 & 15 & 8 & 15 & 11 & 14 & 11 \\
\hline $\begin{array}{l}\text { Teratozoospermic- } \\
\text { index }(<1.8)\end{array}$ & 1.2 & 1.8 & 1.4 & 1.4 & 1.4 & 1.1 & 1.9 & 1.7 & 1.5 & 1.5 & 1.5 & 1.3 & 1.2 & 1.3 & 1.5 \\
\hline $\begin{array}{l}\text { Volume } \\
\text { ejaculate (mL) }\end{array}$ & 4.5 & 6.3 & 1.5 & 1.9 & 4.1 & 4.6 & 1.2 & 2.8 & 2.5 & 3.2 & 2.8 & 4.9 & 4.6 & 4.5 & 7.0 \\
\hline
\end{tabular}

paired transformation of germ cells regardless of the time of surgery, as well as uni- or bilaterality of cryptorchid gonads, were infertile $(4,11)$. Therefore, whether or not the patient will achieve normal fertility following successful surgery depends mainly upon the presence of Ad spermatogonia at the time of orchiopexy $(4,11)$. At least half of cryptorchid population undergoing surgery had no Ad spermatogonia and consequently were candidates for hormonal treatment (7). It is known that a testis in an intra-abdominal position has in general bad testicular histology beyond one year of age, and that a testis in pre-scrotal position has a better or is more close to normal testicular histology $(8,11)$. However, in all positions, although with different incidences, the testes with no Ad spermatogonia and $<0.2$ germ cell per tubule could be observed. Thus, the histological findings distinguished those patients who specifically required additional treatment than testicular position at surgery, albeit the fact that $90 \%$ of boys with intra-abdominal testes probably require hormonal treatment. In this study only two patients; one of each group had their testis located in the abdomen, therefore the study is comparable also with regard to testicular position found at surgery. In male gonadotropin secretion which increases from 2 to 4 months after birth stimulating Leydig cells to secrete testosterone (12-14). Testosterone increase is blunted in cryptorchid boys $(13,14)$. This insufficient testosterone secretion is responsible for impaired transformation of gonocytes into Ad spermatogonia (4,5,11,15-17). Additional rationale for LH-RHa treatment was based on the histological analyses of undescended testes in infancy $(4,5,11,15-20)$. 


\section{Treatment of Cryptorchid Boys with LH-RH Analogue}

Table 3 - Characteristics of the 15 patients with cryptorchidism initially treated with surgery at follow up after puberty.

\begin{tabular}{|c|c|c|c|c|c|c|c|c|c|c|c|c|c|c|c|}
\hline Patient & 16 & 17 & 18 & 19 & 20 & 21 & 22 & 23 & 24 & 25 & 26 & 27 & 28 & 29 & 30 \\
\hline $\begin{array}{l}\text { Age at } \\
\text { surgery/years }\end{array}$ & 2 & 2 & 3 & 2 & 5 & 6 & 4 & 5 & 6 & 5 & 4 & 6 & 6 & $<1$ & 2 \\
\hline $\begin{array}{l}\mathrm{S} / \mathrm{T} \text { (germ } \\
\text { cells/tubules) }\end{array}$ & 0.2 & 0 & 0 & 0 & 0.2 & 0.01 & 0.04 & 0.01 & 0 & 0.02 & 0.1 & 0 & 0.1 & 0.2 & 0.04 \\
\hline Ad/tubule & 0 & 0 & 0 & 0 & 0 & 0 & 0 & 0 & 0 & 0 & 0 & 0 & 0 & 0 & 0 \\
\hline $\begin{array}{l}\text { Age at } \\
\text { spermiogram }\end{array}$ & 20 & 19 & 21 & 20 & 25 & 18 & 22 & 23 & 25 & 24 & 20 & 21 & 23 & 24 & 20 \\
\hline $\begin{array}{l}\text { Tanner stage } \\
\text { genital } \\
\text { development }\end{array}$ & V & V & $\mathrm{V}$ & $\mathrm{V}$ & $\mathrm{V}$ & $\mathrm{V}$ & V & V & $\mathrm{V}$ & V & $\mathrm{V}$ & $\mathrm{V}$ & $\mathrm{V}$ & $\mathrm{V}$ & $\mathrm{V}$ \\
\hline $\begin{array}{l}\text { Sperm } \\
\text { concentration/ } \\
\text { ejaculate }\end{array}$ & 0 & 1 & 6 & 14 & 0.1 & 2.2 & 18 & 9 & 0.1 & 13 & 2 & 0.1 & 13 & 0 & 0 \\
\hline $\begin{array}{l}\text { Normal } \\
\text { morphology } \\
(\geq 14 \%)\end{array}$ & 0 & 0 & 0 & 0 & 0 & 0 & 0 & 0 & 0 & 0 & 0 & 0 & 0 & 0 & 0 \\
\hline $\begin{array}{l}\text { Volume } \\
\text { ejaculate } \\
(\mathrm{mL})\end{array}$ & 3.8 & 5 & 2.9 & 3 & 4.2 & 5 & 5.2 & 5 & 4.2 & 5.1 & 8.2 & 3.8 & 5 & 4.5 & 4.6 \\
\hline
\end{tabular}

The LH-RH analogue (Buserelin) given on alternate days for a period of five months in a previous study caused no inhibition of gonadotropin secretion (21). Moreover, LH values determined in the first morning urine were higher at the end of the treatment (21). Six months LH-RHa treatment increased the number of germ cells in cryptorchid testis $(7,21)$. This increase was age dependent (7). The best results were achieved if the cryptorchid boys were treated before the age of seven years, implying that successful treat- ment of impaired mini-puberty should be performed before this age.

In 1997, we presented results of fertility outcome in cryptorchid boys who were treated with a LH-RH analogue at the age of 8 years and older. Compared with surgery as the only treatment, a significant amelioration, but not normalization, of sperm concentration was achieved in the treated group (22). This result showed that LH-RHa treatment had a lasting effect upon spermatogonial development.

Table 4 - Characteristics of genitalia in boys treated with LH-RHa before and after treatment.

\begin{tabular}{lllr}
\hline Testicular Volume (mL) & Before Treatment & After Treatment & p Value \\
\hline Cryptorchid testis & $1.4(95 \% \mathrm{CI} ; 0.8-2.1)$ & $1.2(95 \% \mathrm{CI} ; 1-3.2)$ & 0.65 \\
Descended testis & $1.2(95 \% \mathrm{CI} ; 1-3.2)$ & $1.4(95 \% \mathrm{CI} ; 1-2.5)$ & 0.52 \\
Penis length $(\mathrm{cm})$ & $4.5(\mathrm{CI} ; 4-5)$ & $5.0(95 \% \mathrm{CI} ; 4.5-6)$ & $<0.001$ \\
\hline
\end{tabular}


Table 5 - Summary of characteristics.

\begin{tabular}{lccc}
\hline & LH-RHa Treatment & Surgery “Alone” & p Value \\
\hline Age at surgery (year) & $3(95 \% \mathrm{CI} ; 2-4)$ & $4(95 \% \mathrm{CI} ; 2-6)$ & $=0.35$ \\
S/T at surgery & $0(95 \% \mathrm{CI} ; 0-0.05)$ & $0.02(95 \% \mathrm{CI} ; 0-2)$ & $=0.22$ \\
Ad spermatogonia at surgery & 0 & 0 & \\
Age at spermiogram (year) & $19(95 \% \mathrm{CI} ; 18-22)$ & $21(95 \% \mathrm{CI} ; 18-25)$ & $<0.02$ \\
Sperm count/ejaculate (mio) & $90(95 \% \mathrm{CI} ; 53-164)$ & $1.0(95 \% \mathrm{CI} ; 0-13)$ & $=0.000008$ \\
Normal morphology & $11 \%(95 \% \mathrm{CI} ; 0-21)$ & 0 & \\
Ejaculate volume (mL) & $4.1(95 \% \mathrm{CI} ; 1.2-7)$ & $4.6(95 \% \mathrm{CI} ; 2.9-8.2)$ & $=0.074$ \\
\hline
\end{tabular}

To analyze the efficacy of the LH-RHa (Buserelin) treatment in boys younger than 7 years, we treated unilateral cryptorchid patients with a high infertility risk according to their testicular histology. The recruitment of patients for this study was designed to be balanced [see statistics section]. From 181 ex-unilateral cryptorchid males who were only surgically treated [representing entire group studied] 15 patients fulfilled the entry requirements for the study. Consequently, we invited our first 19 ex-unilateral cryptorchid males, who had LH-RHa treatment and were older than 18 years, to participate in the study. Fifteen of the first consecutive responders entered the study Spermiogram results showed that 13 of 15 unilateral cryptorchid males had a normal sperm concentration. In addition, the distribution of the fertility patterns of the sperm morphology was identical to that of the normal fertile population (10). Furthermore, in those males with a P-pattern morphology, an excellent sperm concentration will compensate, with a significantly better chance of inducing pregnancy (23). Normalization of the sperm concentration in $86 \%$ of unilateral cryptorchid males, who were in the high risk group for developing infertility, profoundly changes our current concept of cryptorchidism treatment. For the first time, it is possible to demonstrate that infertility caused by cryptorchidism that was believed to be a congenital malformation can be successfully corrected if adequately treated.
In conclusion, infertility induced by cryptorchidism is an endocrine disease of impaired minipuberty. Treatment with a LH-RHa before the age of six years following a successful orchiopexy resulted in the normalization of sperm parameters in the vast majority of patients. Since not all patients with unilateral cryptorchidism belong to the infertility risk group, some will profit from early surgery without need for subsequent LH-RHa treatment. Testicular biopsy is the only diagnostic procedure capable of identifying patients who need to be treated with LH-RHa following successful surgery. Because of its important prognostic value, a testicular biopsy should be routinely performed during the orchiopexy.

\section{ACKNOWLEDGMENT}

This study was sponsored in part by the Swiss National Science Foundation. Dr. Mauro Buser, from the Institute for Statistics, Riehen Switzerland, performed the statistical analyses.

\section{CONFLICT OF INTEREST}

None declared. 


\section{REFERENCES}

1. Trussell JC, Lee PA: The relationship of cryptorchidism to fertility. Curr Urol Rep. 2004; 5: 142-8.

2. Charny $\mathrm{CW}$ : The spermatogenic potential of the undescended testis before and after treatment. J Urol. 1960; 83: 697-705.

3. Ludwig G, Potempa J: Optimal time for treating cryptorchism (author's transl). Dtsch Med Wochenschr. 1975; 100: 680-3.

4. Hadziselimovic F, Herzog B: The importance of both an early orchidopexy and germ cell maturation for fertility. Lancet. 2001; 358: 1156-7.

5. Hadziselimovic F, Zivkovic D, Bica DT, Emmons LR: The importance of mini-puberty for fertility in cryptorchidism. J Urol. 2005; 174: 1536-9; discussion 1538-9.

6. Hadziselimovic F, Höcht B: Prospectives. In: Hadziselimovic F (ed.), Cryptorchidism: Management and Implications. Berlin, Springer-Verlag. 1983; pp. 135.

7. Hadziselimovic F, Huff D, Duckett J, Herzog B, Elder J, Snyder HM 3rd, et al.: Treatment of cryptorchidism with low doses of buserelin over a 6-months period. Eur J Pediatr. 1987; 146(Suppl 2): S56-8.

8. Hadziselimovic F, Hecker E, Herzog B: The value of testicular biopsy in cryptorchidism. Urol Res. 1984; 12: 171-4.

9. World Health Organization. WHO Laboratory Manual for the Examination of Human Semen and SemenCervical Mucus Interaction, 4th ed. Cambridge, Cambridge University Press. 1999; pp. 60-61.

10. Kruger TF, Van der Merwe J, Van Waart J: The Tygerberg Strict Criteria: What Are the Clinical Thresholds for in vitro Fertilization. Intrauterine Insemination, and in vivo Fertilization? In: Kruger TF, Franken DR (eds.). Atlas of Human Sperm Morphology Evaluation. London, Taylor \& Francis, 2004:13-18.

11. Hadziselimovic F, Hocht B, Herzog B, Buser MW: Infertility in cryptorchidism is linked to the stage of germ cell development at orchidopexy. Horm Res. 2007; 68: 46-52.

12. Forest MG, Sizonenko PC, Cathiard AM, Bertrand J: Hypophyso-gonadal function in humans during the first year of life. 1. Evidence for testicular activity in early infancy.J Clin Invest. 1974; 53: 819-28.

13. Job JC, Toublanc JE, Chaussain JL, Gendrel D, Roger M, Canlorbe P: The pituitary-gonadal axis in cryptorchid infants and children. Eur J Pediatr. 1987; 146(Suppl 2): S2-5.
14. Hamza AF, Elrahim M, Elnagar, Maaty SA, Bassiouny E, Jehannin B: Testicular descent: when to interfere? Eur J Pediatr Surg. 2001; 11: 173-6.

15. Hadziselimovic F, Thommen L, Girard J, Herzog B: The significance of postnatal gonadotropin surge for testicular development in normal and cryptorchid testes. J Urol. 1986; 136: 274-6.

16. Hadziselimovic F, Emmons LR, Buser MW: A diminished postnatal surge of Ad spermatogonia in cryptorchid infants is additional evidence for hypogonadotropic hypogonadism. Swiss Med Wkly. 2004; 134: 381-4.

17. Zivkovic D, Bica DT, Hadziselimovic F: Relationship between adult dark spermatogonia and secretory capacity of Leydig cells in cryptorchidism. BJU Int. 2007; 100: 1147-9; discussion 1149.

18. Hadziselimovic F, Herzog B, Huff DS, Menardi G: The morphometric histopathology of undescended testes and testes associated with incarcerated inguinal hernia: a comparative study. J Urol. 1991; 146: 627-9.

19. Huff DS, Hadziselimovic F, Snyder HM 3rd, Blyth B, Duckett JW: Early postnatal testicular maldevelopment in cryptorchidism. J Urol. 1991; 146: 624-6.

20. Huff DS, Fenig DM, Canning DA, Carr MG, Zderic SA, Snyder HM 3rd: Abnormal germ cell development in cryptorchidism. Horm Res. 2001; 55: 11-7.

21. Hadziselimovic F, Hoecht B, Herzog B, Girard J: Does Long Term Treatment with Buserein Improve the Fertility Chances of Cryptorchid Testes? In: Labrie F, Belanger A, Dupont A. (ed.), LH-RH and its Analogues. Amsterdam, Elsevier. 1984.

22. Hadziselimovic F, Herzog B: Treatment with a luteinizing hormone-releasing hormone analogue after successful orchiopexy markedly improves the chance of fertility later in life. J Urol. 1997; 158: 1193-5.

23. Montanaro Gauci M, Kruger TF, Coetzee K, Smith K, Van Der Merwe JP, Lombard CJ: Stepwise regression analysis to study male and female factors impacting on pregnancy rate in an intrauterine insemination programme. Andrologia. 2001; 33: 135-41.

Accepted after revision:

May 5, 2008

Correspondence address:

Dr. Faruk Hadziselimovic

Kindertagesklinik Liestal

Oristalstrasse 87

Liestal, 4410, Switzerland

Fax:+41 61 922-0533

E-mail: praxis.oris@bluewin.ch 


\section{EDITORIAL COMMENT}

The present study reinforce the concept that cryptorchidism is resultant of hormonal alteration that affect both testes, even when the alteration is unilateral.

The study design evidences that the mere relocation of an ectopic gonad in the correct anatomic position is not enough to grant future fertility.

Hormonal therapy for cryptorchidism was confused with an alternative therapy for surgery. Nevertheless, the main objective of the hormonal therapy is to improve the histological quality of the gonad, improving future fertility rates.

This study indicates that hormonal therapy acts synergically with surgery for obtaining nearly normal fertility rates in the future.

\section{REFERENCES}

1. Lee PA, Bellinger MF, Coughlin MT: Correlations among hormone levels, sperm parameters and paternity in formerly unilaterally cryptorchid men. J Urol. 1998; 160: 1155-7; discussion 1178.

\section{EDITORIAL COMMENT}

Cryptorchidism is one of the most common congenital pathologies in boys. Treatment of this congenital anomaly concerns the possibility of diminishing risk of malignant degeneration and improving fertility. Surgery is the best treatment for cryptorchidism but there are many studies showing good results for testicular migration after therapy with $\mathrm{hCG}$ or with GnRH (1-3). The evidence for the use of hCG vs. GnRH shows advantages for $\mathrm{hCG}$, and a recent review also shows that there is evidence that luteinizing hormone releasing hormone (LH-RH) is more effective than placebo (4) The hormonal treatment in cryptorchidism is controversial. Considering the efficacy and the possible side effects of the hormonal treatment a recent meta-analysis recommended that the hormonal treatment of cryptorchidism could not be further recommended (5). An experimental study
2. Coughlin MT, Bellinger MF, Lee PA: Age at unilateral orchiopexy: effect on hormone levels and sperm count in adulthood. J Urol. 1999; 162: 986-8; discussion 989.

3. Taskinen S, Wikström S: Effect of age at operation, location of testis and preoperative hormonal treatment on testicular growth after cryptorchidism. J Urol. 1997; 158: 471-3.

4. Lala R, Matarazzo P, Chiabotto P, Gennari F, Cortese MG, Canavese F, et al.: Early hormonal and surgical treatment of cryptorchidism. J Urol. 1997; 157: 1898901.

5. Bica DT, Hadziselimovic F: Buserelin treatment of cryptorchidism: a randomized, double-blind, placebocontrolled study. J Urol. 1992; 148: 617-21.

Dr. Marcelo P. Braz Section of Pediatric Urology Bonsucesso General Hospital Rio de Janeiro, RJ, Brazil E-mail:drmarcelo.braz@gmail.com

shows that hCG impairs the seminiferous tubule histology in normal testes of rats (6). There is still controversy on whether it may be useful as an adjunct to surgery to stimulate germ cells. Current evidence suggests that hormonal therapy may not stimulate transformation of neonatal gonocytes but may trigger prepubertal mitosis of primary spermatocytes (7). Subfertility is considered the main consequence of cryptorchidism even after timely orchiopexy. Gonadotropin-releasing hormone $(\mathrm{GnRH})$ treatment appears to improve fertility later in life by inducing germ cell maturation. A recent paper shows that neoadjuvant $\mathrm{GnRH}$ treatment improves fertility index in prepubertal cryptorchidism (8). The great contribution of this paper is the evaluation of seminal parameters in patients that was submitted to orchiopexy with hormonal treatment in childhood. This paper tends 
to confirm the beneficial effects of medical treatment after orchiopexy in patients with high risk of infertility confirmed by testicular biopsy. One important conclusion of this paper is that testicular biopsy should be performed routinely to evaluate testicular histology during surgery in patients with cryptorchidism.

\section{REFERENCES}

1. Bica DT, Hadziselimovic F: Buserelin treatment of cryptorchidism: a randomized, double-blind, placebocontrolled study. J Urol. 1992; 148: 617-21.

2. Favorito LA, Toledo Filho JS: Study of testicular migration after treatment with human chorionic gonadotropin in patients with cryptorchidism. Braz J Urol, 27: 270-274, 2001

3. Gill B, Kogan S: Cryptorchidism. Current concepts. Pediatr Clin North Am. 1997; 44: 1211-27.

4. Henna MR, Del Nero RG, Sampaio CZ, Atallah AN, Schettini ST, Castro AA, et al.: Hormonal cryptorchi- dism therapy: systematic review with metanalysis of randomized clinical trials. Pediatr Surg Int. 2004; 20: 357-9.

5. Thorsson AV, Christiansen P, Ritzén M: Efficacy and safety of hormonal treatment of cryptorchidism: current state of the art. Acta Paediatr. 2007; 96: 628-30.

6. Kaya C, Karaman MI, Pirincci N, Ozturk M, Yilmazgumrukcu G: Human chorionic gonadotropin deteriorates the histology of rat testes. Urol Int. 2006; 76: 274-7.

7. Ong C, Hasthorpe S, Hutson JM: Germ cell development in the descended and cryptorchid testis and the effects of hormonal manipulation. Pediatr Surg Int. $2005 ; 21: 240-54$.

8. Schwentner C, Oswald J, Kreczy A, Lunacek A, Bartsch G, Deibl M, et al.: Neoadjuvant gonadotropinreleasing hormone therapy before surgery may improve the fertility index in undescended testes: a prospective randomized trial. J Urol. 2005; 173: 974-7.

\section{Dr. Luciano A. Favorito}

Urogenital Research Unit

State University of Rio de Janeiro

Rio de Janeiro, RJ, Brazil

E-mail:favorito@urogenitalresearch.org 